\title{
Use of Light-Cured Resin to Manufacture Occlusal Splints: Report of Two Cases
}

\author{
Mieszko WIĘCKIEWICZ ${ }^{1}$ \\ Marta MIERNIK ${ }^{2}$ \\ Włodzimierz WIĘCKIEWICZ² \\ ${ }^{1}$ Division of Dental Materials, Dental School, Wrocław Medical University, Wrocław, Poland \\ ${ }^{2}$ Division of Implantoprosthetics and Functional Disturbances of the Stomatognathic System, Dental School, \\ Wrocław Medical University, Wrocław, Poland
}

\begin{abstract}
This article presents selected cases of patients with functional disorders of the stomatognathic system. This group of patients had a need to made different types of removable occlusal splints. In the past, occlusal appliances were made mostly using self-cured acrylate materials, which for many years had no replacements. The rapid development of dental materials technology led to creation of thermo-formable materials and resins, which can successfully replace traditional acrylic materials in daily clinical practice. A practical application of light-cured resin in the fabrication of the occlusal splints in two clinical cases is reported and discussed herein.
\end{abstract}

Key Words: light-cured resin, occlusal splints, functional disorders of the stomatognathic system, occlusal parafunctions.

\section{INTRODUCTION}

Improvement of the health status of patients after use of removable occlusal appliances made of conventional materials has been repeatedly demonstrated and described (1-3).

Commonly used in construction of prostheses and occlusal splints material is chemically hardened acrylate, which has many disadvantages e.g. allergic reaction to the monomer present in self-cured acrylate and limited time of work with this material.

The development of science has allowed a study on the materials that will help to achieve better and more biocompatible clinical solutions. Examples of such materials are light-cured resins, which are widely used in modern dentistry. They can be used in the splint therapy of occlusal disorders circuit, dysfunction of masticatory motor system and orthognathic surgery $(4,5)$. Lightcured resins allow for more safe and healthy occlusal splint manufacturing. There is also no working time limit during the preparation of the occlusal appliance made of resin activated by light.

One of the commonly known light-polymerized dimethacrylates is Lightdon Splint (Dreve Dentamid Gmbh, Unna, Germany). Lightdon resin is made of chemically tetrahydrofurfuryl-2-methacrylate, polyurethanacrylate, poly-iso-butylmethacrylate and photoinitiator, respectively, 30-35, 25, 35-40 and 0.5-0.7 percentage. It connects to the thermoplastic plates via product "Lightdon Bonding" and allows for reduction of relieve items and correction of occlusal guidance. After curing the last resin layer, the manufacturer recommends covering it by "Plaquit" lacquer to prevent accumulation of dental plaque (6). After polishing and coating by lacquer, the resin should have an ultimate aesthetics. According to the manufacturer, wavelength of light emitted by the UV curing lamp should be 300$500 \mathrm{Nm}$. Exposure times of components are: Lightdon Bonding - 1 min; Lightdon Splint: 4-5 min; and Plaquit 3-5 min. The curing lamp Voco Individo Light Box was used (Voco Gmbh, Cuxhaven, Germany) for the curing procedures.

This paper reports a practical application of this light-curing resin in the fabrication of occlusal splints for selected patients by presenting and dicussing two clinical cases.

Correspodence: Mieszko Więckiewicz, Division of Dental Materials, Dental School, Wroclaw Medical University, 26 Krakowska Street, 50-425 Wrocław, Poland. Tel. +48-66-0478-759. email: m.wieckiewicz@onet.pl 


\section{CASE REPORT}

\section{Case 1}

A female patient, aged 24 years, was admitted to the Division of Implantoloprosthetics and Functional Disturbances of the Stomatognathic System at Wroclaw Medical University, Poland because of the inability to open her mouth widely and pain around regions of the temporomandibular joints (TMJ). In the interview, the patient reported that during the consumption of hard food, spontaneously started to feel pain in the TMJ area. The consequence of that event was to reduce the possibility of opening paragraphs.

The patient also reported that the pain and clicking in the TMJ had appeared sporadically about two years before, but they was underestimated. Physical examination revealed bilateral pain of the TMJ palpation, reduction of mouth opening range, pain and tense of masseter muscles, lateral and medial pterygoid muscles. Intraoral partial posterior occlusion in the anterior dentition and overbite were seen. The presence of abrasive fields on teeth and anemisation of cheek mucosa confirmed patients parafunctional occlusal activity (7).

The diagnostics was expanded by using the $x$-ray lateral transcranial projection. Analysis of radiographs showed reduction of TMJ spaces at the intercuspal position and bilateral decreased translation of condyles at maximum mouth opening.

After careful study, subjective and objective diagnosis was bilateral anterior disc displacement without reduction. Anterior repositioning splint (8), pharmacotherapy and physical therapy were used for treatment. The patient was prescribed a soft diet, avoidance of attempts to open her mouth widely and masseter muscles massages. Due to the pain of the TMJ and tense muscles, it was decided to implement drug treatment in the form of Ibuprofenum $200 \mathrm{mg}$, 4 times a day, for 7 days $(9,10)$, and 10 treatments of electrical stimulation of masseter muscles.

The anatomical impression of mandible was done using alginate in order to create plaster cast, which was used for the implementation of the base splint with a 2-mm-thick thermoplastic plate, using a deep formation technique. The plate was covered by Lightdon Bonding. In the patient's mouth, shafts in both lateral regions were made, using light-cured resin Lightdon Splint. The splint was finally adjusted in the mouth by using an occlusal paper. At the end the polished surface of appliance was coated by Plaquit lacquer (Fig. 1). Each component of the Lightdon Splint system was polymerized separately according to the manufacturer's instructions.

Check-up visits were carried out after 1 day, 3 days, and later at weekly intervals. On each visit, occlusal contacts on the splint were checked and appropriate adjustments were made. The patient used the appliance at night and a few hours during the day.

After 2 weeks of the treatment, the patient reported decrease of pain and increase in the mouth opening range. The examination showed lack of pain on palpation in the TMJ area and reduction of tension in the masseter, lateral and medial pterygoid muscles. It was recommended to use a splint by the next 6 weeks and after symptoms withdrawal to start orthodontic therapy in order to maintain treatment results $(11,12)$.

\section{Case 2}

A male patient, aged 41 years, was admitted to the Division of Implantoloprosthetics and Functional Disturbances of the Stomatognathic System, Wroclaw Medical University, Poland, because of habitual biting the cheek mucosa on the right side. In the interview, the patient reported that the pain in this area bothered him in times of mental burden (13).

Physical examination revealed anemisation, fresh and healing wounds on the right cheek mucosa located in the line of occlusion. Moreover, abrasive surfaces on teeth, dental impressions on the lateral surface of the tongue and hypertrophy and increased of masseter

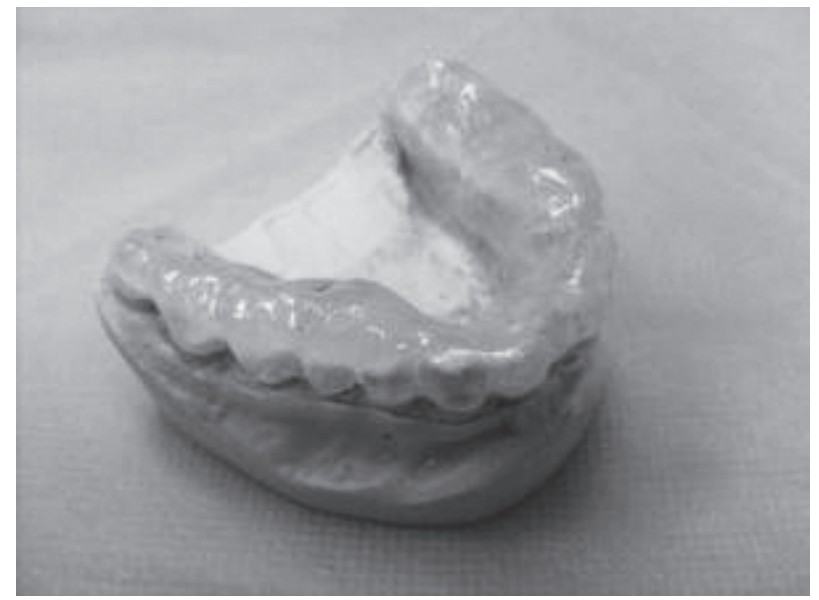

Figure 1. Extraoral picture of the anterior repositioning splint, in which the relieve elements are made of light-cured resin. 
tension of muscles were observed. These symptoms indicated parafunctional occlusal activity. It was decided to make the relaxation splint with the vestibular screen in order to prevent biting the right cheek mucosa. The patient was advised to exercise in the form of inflating the cheeks 3 times a day for $5 \mathrm{~min}$.

Anatomical impression of mandible was taken in order to prepare a cast, which was used for the implementation of the base splint with a 2-mm-thick thermoplastic plate, using a deep formation technique. Then anatomical impression of upper jaw and wax registration of occlusion were performed. The plate was covered with a Lightdon Bonding. Vestibular screen was made of resin Lightdon in semi-individual articulator, including teeth from 43 to 47 . Splint was adjusted in the patient's mouth, using occlusal paper. Finally the splint was polished and coated with lacquer Plaquit (Fig. 2). Each component of the Lightdon Splint system was polymerized separately according to the manufacturer's instructions.

Check-up visits were carried out after 3 days, after 1 week and after 2 weeks. Every time contacts between teeth and splint were checked and appropriate adjustments were done. The patient was using the appliance at night.

After 10 days of treatment the patient reported no pain on the right cheek. Clinical examination, revealed no new injuries to the buccal mucosa. The patient was recommended to continue using the splint and the next check-up visit was arranged after 4 weeks.

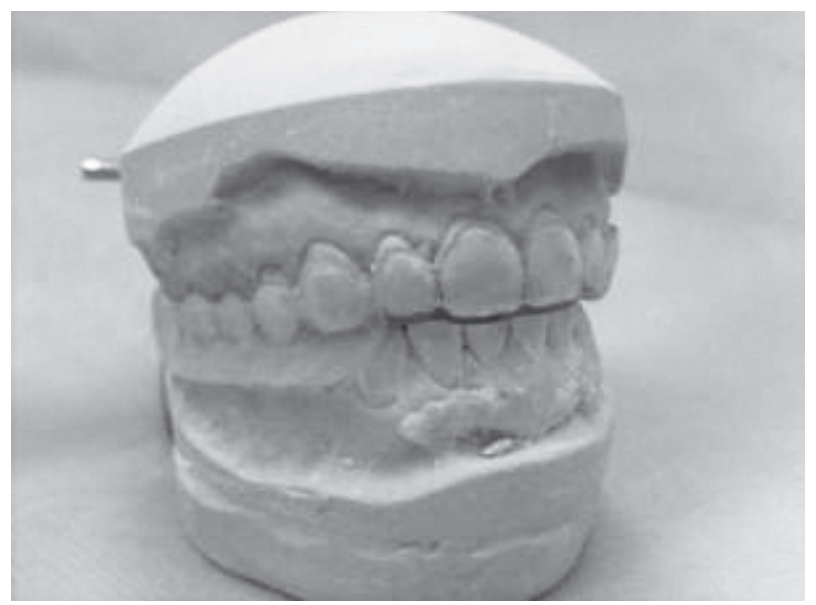

Figure 2. Extraoral picture of relaxation splint with vestibular screen, which is made of light-cured resin in the right lateral segment, protecting the cheek mucosa.

\section{DISCUSSION}

The success of light-cured resin depends on good physical properties (resistance to bending, modulus of elasticity, the adsorption of water, polymerization shrinkage), similar to the chemical-hardened materials $(14,15)$. In addition, resins polymerized by light increase the working time of materials and decrease their plasticity and toxicity compared with traditional chemical polymerized materials (16). Health care workers are exposed to skin and respiratory allergies (17). The use of light-cured resins eliminate allergic hypersensitivity to the monomer among not only patients, but also the dental staff.

All those advantages make light-cured resin a perfect material for the manufacture of occlusal splints (18). Tests performed by Danesh et al. (19) showed that light-polymerized resins have adequate hardness, allowing opposition to occlusal forces. Long working time of Lightdon Splint led to perform the necessary relieve and guidance elements on the occlusal surface of appliance properly and without haste. Using these materials eliminates the irritating smell of chemical-hardened acrylate, residual monomer and the possibility of thermal damage to tissues during intraoral polymerization. Resin bond strength to thermoplastic plates is satisfactory. These features allow to obtain quickly the right construction of the occlusal splint.

Due to precise examination and diagnosis effective treatment can be planned. Follow-up visits confirmed that the resin structure, aesthetic and shape did not change in a noticeable way. There was no loss of bond strength between resin and thermoplastic plates. The authors did not observe tissue irritation. None of the patients complained about the material.

In conclusion, several positive features of lightcured resin make constructing of occlusal splints easier and more biocompatible. According to the authors' clinical experience with described composite material it can be stated that this material is aesthetic and has adequate bond strength to the thermoplastic plates. These features indicate that the light-cured materials can replace the chemically polimerized acrylics in clinical practice in the manufacture of occlusal splints. Accurate diagnostics of functional disorders of the stomatognathic system allows choosing the primary therapy and supportive treatment, which determines the success in dealing with the patient (20).

This way, the use of light-cured materials 
play a great role in modern dentistry. It provides new opportunities in occlusal therapy making the fabrication of splints much easier for the dentist and comfortable for patient. According to obtained results, it can be stated that light-cured materials should be commonly used alternative method for various types of occlusal appliances.

\section{RESUMO}

Este artigo apresenta casos selecionados de pacientes com distúrbios funcionais do sistema estomatognático, que necessitavam de diferentes tipos de placas oclusais removíveis. No passado, as placas oclusais eram fabricadas, em sua maioria, utilizando-se materiais acrílicos autopolimerizáveis, sem que houvesse substituto por muitos anos. O rápido desenvolvimento da tecnologia dos materiais odontológicos levou ao desenvolvimento de materiais termo-moldáveis e resinas, os quais podem substituir os tradicionais materiais acrílicos com sucesso na prática clínica diária. A aplicação prática da resina fotopolimerizável na fabricação de placas oclusais em dois casos clínicos é relatada e discutida neste trabalho.

\section{REFERENCES}

1. Noriyuki N, Masahiko F, Tomohiro I, Kazunobu K, Toshihiko M. Effects of jaw clenching while wearing an occlusal splint on awareness of tiredness, bite force, and EEG power spectrum. J Prosthot Res 2009;53:120-125.

2. Fayed MM, El-Mangoury NH, El-Bokle DN, Belal AI. Occlusal splint therapy and magnetic resonance imaging. World J Orthod 2004;5:133-140.

3. Sung-Wen $\mathrm{CH}$, Ching-Ya CH, Jau-Rong L, Che-Yi L, Chang-Ta $\mathrm{CH}$. Treatment Effects of maxillary flat occlusal splints for painful clicking of the temporomandibular joint. Kaohsiung J Med Scien 2010;26:299-307.

4. Magdaleno F, Ginestal E. Side effects of stabilization occlusal splints: a report of three cases and literature review. Cranio 2010;28:128-135.

5. Danesh G, Lippold C, Joos U, Meyer U. Technical and clinical assessment of the use of a new material-based splint in orthognathic surgery. Int J Oral Maxillofac Surg 2006;35:796-799.

6. Lightdon Splint. Safety Data Sheet. Unna, Germany 2007.
7. Slavicek R. Relationship between occlusion and temporomandibular disorders: implications for the gnathologist. Am J Orthod Dentofac Orthop 2011;139:10-14.

8. Okeson JP. Long-term treatment of disk-interference disorders of the temporomandibular joint with anterior repositioning occlusal splints. J Prosthet Dent 1988;60:611-616.

9. Schütz TC, Andersen ML, Tufik S. Effects of COX-2 inhibitor in temporomandibular joint acute inflammation. J Dent Res 2007;86:475-479.

10. Dionne RA, Berthold CW. Therapeutic uses of non-steroidal antiinflammatory drugs in dentistry. Crit Rev Oral Biol Med 2001; 12 : 315-330.

11. Brenkert DR. Orthodontic treatment for the TMJ patient following splint therapy to stabilize a displaced $\operatorname{disk}(\mathrm{s})$ : a systemized approach. Part I, TMJ orthodontic diagnosis. Cranio 2010;28:193199.

12. Brenkert DR. Orthodontic treatment for the TMJ patient following splint therapy to stabilize a displaced $\operatorname{disk}(\mathrm{s})$ : a systemized approach. Part II. Cranio 2010;28:260-265.

13. Jovanović S, Gajić I, Mandić B, Mandić J, Radivojević V. Oral lesions in patients with psychiatric disorders. Srp Arh Celok Lek 2010;138:564-569.

14. Danesh G, Lippolda C, Mischkea KL, Varzideha B, Reinhardt KJ, Dammaschke T, et al.. Polymerisation characteristics of light- and auto-curing resins for individual splints. Den Mater 2006;22:426433.

15. Danesh G, Lippold C, Ziebura T, Reinhardt KJ, Schäfer E, Ehmer U. In-vitro investigations on suitability of light-cured resins for interocclusal splints: part I: mechanical properties. J Orofac Orthop 2006;67:127-137.

16. Alves P, Bolognese AM, Polley JW, Figueroa AA. Use of visible light-curing acrylic resins to manufacture occlusal splints: health considerations for clinicians and laboratory personnel. J Oral Maxillofac Surg 2008;66:2638-2641.

17. Seppäläinen AM, Rajaniemi R. Local neurotoxicity of methylmeth-acrylate among dental technicians. Am J Ind Med 1984;5:471-477.

18. Dahl J, Frangou-Polyzois MJ, Polyzois GL. In vitro biocompability of denture relining materials. Gerodontology 2006;23:17-22.

19. Danesh G, Lippold C, Ziebura T, Reinhardt KJ, Schäfer E, Ehmer U. In-vitro investigations on suitability of light-cured resins for interocclusal splints: part II: Surface Hardness. J Orofac Orthop 2006;67:138-147.

20. Okeson JP, de Leeuw R. Differential diagnosis of temporomandibular disorders and other orofacial pain disorders. Dent Clin North Am 2011;55:105-120. 